\begin{tabular}{|c|c|c|}
\hline $\begin{array}{c}\text { RESEARCH } \\
\text { ARTICLE }\end{array}$ & $\begin{array}{r}\text { ADVANCE RESEARCF } \\
\text { Volume } 8 \mid \text { Issue } 2 \mid \text { De }\end{array}$ & $\begin{array}{l}\text { OCIAL SCIENCE } \\
-2231-6418\end{array}$ \\
\hline $0=$ & DOI: 10.15740/HAS/ARJSS/8.2/291-293 & Visit us : www.researchjournal.co.in \\
\hline
\end{tabular}

\title{
Knowledge and adoption of home science technologies by the rural women
}

V.V. Jagtap*, J.V. Ekale and M.V. Kulkarni

College of Agriculture, Vasantrao Naik Marathwada Krishi Vidyapeeth, PARBHANI (M.S.) INDIA

\section{ARTICLE INFO :}

Received : 15.09 .2017

Revised : 23.10.2017

Accepted : $\quad 07.11 .2017$

KEY WORDS :

Profile of rural women, Home science technologies

HOW TO CITE THIS ARTICLE :

Jagtap, V.V., Ekale, J.V. and Kulkarni, M.V. (2017). Knowledge and adoption of home science technologies by the rural women. Adv. Res. J. Soc. Sci., 8 (2) : 291293, DOI: 10.15740/HAS/ARJSS/8.2/ 291-293.

*Author for correspondence

\begin{abstract}
The present study was conducted with specific objective to study the "Knowledge and adoption of home science technologies by the rural women" for the study, Aurangabad district was selected purposively and one (KVK) Krishi Vighyan Kendra from Aurangabad were selected, under this KVK ten villages were selected purposively. As regard with the profile rural women majority of the farmers having medium farming experience between 19-32 years, medium annual income, social participation, extension contact, source of information, economic motivation and risk orientation, respectively and education upto primary school level, marginal land holding of the respondents.
\end{abstract}

